\title{
Karakteristik dan Tingkat Akurasi Diagnosis Klinis Terhadap Hasil Histopatologi Tumor Orbita di RS Mata Cicendo Bandung
}

Raudatul Janah, Friska Mardianty

\begin{abstract}
Abstrak
Tumor orbita adalah tumor yang terletak di rongga orbita sebagian merusak jaringan lunak mata, saraf mata dan kelenjar air mata. Neoplasma pada mata ini merupakan masalah yang besar, yaitu kehilangan tajam penglihatan serta mengakibatkan kecacatan baik kosmetik maupun kematian. Tujuan: mengetahui karakteristik pasien tumor orbita dan keakuratan diagnosis klinis terhadap diagnosis histopatologi tumor orbita di RS mata Cicendo bandung periode tahun 2017-2018. Metode: Penelitian ini merupakan studi cross sectional. Teknik penambilan sampel pada penelitian ini adalah menggunakan teknik total sampling yaitu mengambil seluruh populasi menjadi sampel.. Data dikumpulkan secara retrospektif berdasarkan catatan medis berupa umur, jenis kelamin, mata yang terlibat, lokasi tumor, tindakan, diagnosis klinis, hasil pemeriksaan patologi tumor dan keakuratan diagnosis klinis diungkapkan sebagai data frekuensi. Penelitian ini menggunakan uji Chi-square. Hasil: Berdasarkan hasil uji Chi-square didapatkan $p=0,001$ $(p<0,05)$, berarti terdapat hubungan yang signifikan antara diagnosis klinis dengan hasil histopatologis. Simpulan: Semakin akurat diagnosis klinis maka penentuan hasil histopatologisnya tumor orbita di RS mata Cicendo bandung semakin tepat dan akurat.
\end{abstract}

Kata kunci: diagnosis klinis, histopatologi, tumor orbita

\begin{abstract}
Orbital tumors are tumors located in the orbital cavity, which partially damage the soft tissues of the eye, nerve of the eye, and tear glands. This neoplasms is a significant problem, namely a sharp loss of vision and resulting in both cosmetic and death defects. Objectives: To determined the characteristics of orbital tumor patients and the accuracy of the clinical diagnosis of the histopathological diagnosis of orbital tumors in Cicendo Bandung Hospital in the period of 2017-2018. Methods: This was a cross-sectional study design. The sampling technique in this study is to use a total sampling technique that is taking the entire population into a sample. Data analysis Data were collected retrospectively based on medical records in the form of age, sex, eyes involved, tumor location, actions, clinical diagnosis, results of tumor pathology examination, and the accuracy of the clinical diagnosis is expressed as frequency data. This study uses the Chi-square test. Results: Chi-square test was $p=0,001(p<0.05)$ that was a significant relationship between clinical diagnosis and histopathological results. Conclusion: the more accurate the clinical diagnosis, the determination of the histopathological findings of the orbital tumor in Cicendo Bandung eye hospital is more precise and accurate.
\end{abstract}

Keywords: clinical diagnosis, histopathological orbital tumors

Affiliasi penulis: Laboratorium Patologi Anatomi RS. Mata Cicendo, Bandung, Indonesia.

Korespondensi: Raudatul.janah1@gmail.com Telp: 087837356528

\section{PENDAHULUAN}

Tumor orbita adalah tumor yang terletak di rongga orbita sebagian merusak jaringan lunak mata, saraf mata dan kelenjar air mata. Tumor orbita terdiri 
dari primer, sekunder yang merupakan penyebaran dari struktur sekitarnya, atau metastasase. Angka kejadian tumor mata terhitung kecil, namun neoplasma pada mata merupakan masalah yang besar, yaitu kehilangan tajam penglihatan serta mengakibatkan kecacatan baik kosmetik maupun kematian., ${ }^{1,2,3}$ Pemeriksaan histopatologi merupakan pemeriksaan goldstandar pada tumor orbita, meskipun pemeriksaan secara klinis juga hal yang penting. Keakuratan diagnosis klinis dibutuhkan untuk mencegah perkembangan tumor yang lebih invasif dan merupakan acuan pemilihan terapi yang tepat sehingga mengurangi angka morbiditas maupun mortalitas. Terapi tumor orbita dibagi berdasarkan sifat tumor tersebut, apakah tumor bersifat jinak atau ganas. Terapi tumor jinak hanya dengan eksisi dan atau pendekatan konservatif. Namun bila tumor orbita ganas maka memerlukan tindakan biopsi dan redioterapi serta kemoterapi. Tumor orbita juga bisa berasal dari metastasis tumor sekunder. Kebanyakan tumor mata sekunder berasal dari hidung dan sinus paranasal. Prognosis atau angka keberhasilan kelangsungan hidup penderita mencapai $80 \%$, artinya masih ada harapan hidup yang cukup baik. Angka mortalitas sangat dipengaruhi oleh stadium tumor itu sendiri. Tentu saja pada stadium lanjut angka kelangsungan hidup lebih buruk. ${ }^{4,5}$

Di Indonesia, data mengenai tumor orbita masih sangat sedikit sehingga perlunya data baru mengenai tumor orbita tersebut. Berdasarkan permasalahan tersebut, peneliti memandang perlu untuk melakukan penelitian terkait tumor mata yang dampaknya dapat menyebabkan menurunkan angka mortalitas dan morbiditas pasien. Alasan mengapa melakukan penelitian di RS Mata Cicendo Bandung karena rumah sakit ini merupakan rumah sakit khusus rujukan utama dan sebagai rumah sakit pendidikan utama serta sebagai rumah sakit tipe $A$ sehingga rumah sakit ini memiliki sarana dan prasarana yang memadai serta angka kejadian tumor orbita tersebut sangat banyak . Hal tersebut mendasari penulis untuk meneliti karakteristik dan tingkat akurasi diagnosis klinis terhadap hasil histopatologis tumor orbita di RS Mata Cicendo Bandung

\section{METODE}

Penelitian ini merupakan studi deskriptif observasional dengan desain cross sectional. ${ }^{6}$ Teknik pengambilan sampel adalah menggunakan teknik total-sampling yaitu mengambil seluruh populasi menjadi sampel. Semua penderita tumor orbita di RS Mata Cicendo Bandung pada periode tahun 20172018 yang memenuhi kriteria inklusi dan eksklusi. ${ }^{7}$

Data dikumpulkan secara retrospektif berdasarkan catatan medis berupa umur, jenis kelamin, tempat tinggal, mata yang terlibat, lokasi tumor, tindakan, diagnosis klinis, hasil histopatologi tumor dan keakuratan diagnosis klinis diungkapkan sebagai data frekuensi. Data tersebut dianalisis secara komputerisasi. Penelitian ini menggunakan uji Chisquare. Nilai $\mathrm{P}<0,05$ menunjukkan hubungan yang signifikan secara statistik. Penelitian ini telah mendapat persetujuan dari Komite Etik Penelitian Universitas Padjadjaran Bandung Nomor: 1251/UN6.KEP/EC/2019.

\section{HASIL}

Pada penelitian ini didapatkan sampel sebanyak 760 orang yang terdiri atas mayoritas laki-laki sebanyak 421 orang $(55,4 \%)$ dan 339 orang (44,6\%) merupakan perempuan. Karakteristik sampel berdasarkan usia adalah mayoritas usia >45 tahun (lansia) sebanyak 330 orang $(43,4 \%)$, usia $17-45$ tahun (dewasa) 245 orang (32,2\%), usia $<17$ tahun (anak) 185 orang (24,3\%). Keterlibatan mata kebanyakan pada mata kiri/ocular sinistra sebanyak 389 orang $(51,18 \%)$ dengan lokasi di palpebral sebanyak 140 orang (36\%), konjungtiva 77 orang (19.8\%), retrobulbar 29 orang $(7,5 \%)$ dan sisanya sebanyak 143 orang (36,8\%) berada pada lainnya/tidak diidentifikasi hanya menyebut mata kiri, sedangkan pada mata kanan/ocular dextra sebanyak 371 orang $(48,8 \%)$ dimana lokasi di palpebra 130 orang $(35 \%)$, berada pada conjungtiva 88 orang $(23,7 \%), 20$ orang $(5,4 \%)$ berada pada retrobulbar dan sisanya sebanyak 133 orang $(35,8 \%)$ berada pada lainnya/tidak diidentifikasi hanya menyebut mata kanan. Jenis operasi yang dijalani oleh responden mayoritas biopsi sebanyak 277 orang $(36,4 \%)$, biopsi 
seksi sebanyak 14 orang (1,8\%), biopsi insisi sebanyak 6 orang $(0,8 \%)$, orbitotomi 21 orang $(2,8 \%)$, enukleasi 73 orang $(9,6 \%)$, biopsi ekstirpasi 92 orang $(12,1 \%)$ biopsi eksisi 91 orang (12\%) dan sisanya sebanyak 186 orang (24,5) merupakan operasi lainnya.

Tabel 1. Data diagnosis klinis

\begin{tabular}{l|rr}
\hline \multicolumn{1}{c}{ Diagnosis klinis } & Frekuensi & Persentase \\
\hline Lesi/Tumor jinak & $\mathbf{5 1 9}$ & $\mathbf{6 8 , 3}$ \\
Veruka & 24 & 4,6 \\
Kista & 116 & 22,4 \\
Nevus & 68 & 13,1 \\
Granuloma/Radang & 27 & 5,2 \\
OSSN & 34 & 6,6 \\
Massa & 92 & 17,7 \\
Propotosis/massa & 43 & 8,3 \\
retrobulbar & & \\
Lainnya & 115 & 22,2 \\
Lesi/Tumor ganas & $\mathbf{2 4 1}$ & $\mathbf{3 1 , 7}$ \\
Squamous cell Carcinoma & 25 & 10,4 \\
(SCC) & & \\
Basal Cell Carcinoma & 25 & 10,4 \\
(BCC) & & \\
Retinoblastoma & 51 & 21,1 \\
Melanoma & 27 & 11,2 \\
Sebaseous Carcinoma & 1 & 0,4 \\
Limfoma maligna & 54 & 22,40 \\
Meningioma & 11 & 4,6 \\
Glioma & 5 & 2,1 \\
Lainnya & $\mathbf{4 6 0}$ & $\mathbf{1 0 0}$ \\
\hline Total & & \\
\hline & & \\
\hline & & \\
\hline
\end{tabular}

Berdasarkan hasil uji crosstabulation diketahui bahwa dari 543 orang $(71,5 \%)$ yang didiagnosis klinis memiliki tumor jinak dapat dikonfirmasi dengan hasil histopatologis yaitu sebanyak 467 orang (61,5\%) menderita tumor jinak. Sedangkan sisanya sebanyak 76 orang (10\%) menderita tumor ganas. Dari 217 orang $(28,5 \%)$ yang didiagnosis klinis memiliki tumor ganas dan dikonfirmasi dengan hasil histopatologis sebanyak 165 orang (21,7\%) menderita tumor ganas sedangkan sisanya sebanyak 52 orang (6,8\%) memiliki tumor jinak. Hasil Chi-square menunjukkan sebesar 307,838 dengan $p=0,001$ yang kurang dari 0,05 . Artinya pada taraf signifikan 5\% dapat disimpulkan terdapat hubungan yang signifikan antara diagnosis klinis dengan hasil histopatologis, hal ini pula menunjukan bahwa semakin akurat diagnosis klinis maka semakin akurat dan tepat hasil histopatologis dan begitu juga dengan sebaliknya.

Tabel 2. Data hasil histopatologi

\begin{tabular}{|c|c|c|}
\hline Hasil Histopatologi & Frekuensi & Persentase \\
\hline Lesi/Tumor jinak & 543 & 71,4 \\
\hline Vitreal hemoragik & 11 & 2 \\
\hline Radang & 92 & 17 \\
\hline Epitelial cyst & 68 & 12,5 \\
\hline Kista dermoid & 36 & 6,6 \\
\hline Kista epidermoid & 17 & 3,1 \\
\hline OSSN & 29 & 5,3 \\
\hline Epitelial jinak lain & 85 & 15,7 \\
\hline Nevus & 76 & 14 \\
\hline Neurogenik jinak & 11 & 2 \\
\hline Meseenkim jinak & 29 & 5,3 \\
\hline Lakrimal jinak & 8 & 1,5 \\
\hline Vaskuler & 38 & 7 \\
\hline Limfoid hiperplasia & 43 & 8 \\
\hline Lesi/Tumor ganas & 217 & 28,6 \\
\hline Meningioma & 10 & 4,6 \\
\hline Epitel ganas & 94 & 43,3 \\
\hline $\begin{array}{l}\text { Basal cell carcinoma } \\
\text { (BCC) }\end{array}$ & 24 & 25,3 \\
\hline Melanoma & 23 & 24,7 \\
\hline $\begin{array}{l}\text { Squamous cell } \\
\text { carcinoma (SCC) }\end{array}$ & 47 & 50 \\
\hline Adneksa ganas & 18 & 8,3 \\
\hline Sebaceous carcinoma & 17 & 94,4 \\
\hline $\begin{array}{l}\text { Ductal eccrin } \\
\text { carcinoma }\end{array}$ & 1 & 5,6 \\
\hline $\begin{array}{l}\text { Kelenjar lacrimal } \\
\text { ganas }\end{array}$ & 8 & 3,7 \\
\hline $\begin{array}{ll}\text { Adenoid } & \text { kistik } \\
\text { karsinoma } & \end{array}$ & 3 & 37,5 \\
\hline $\begin{array}{l}\text { Mucoepidermoid } \\
\text { carcinoma }\end{array}$ & 1 & 12,5 \\
\hline Malignant mix tumor & 1 & 12,5 \\
\hline $\begin{array}{l}\text { Adenocarcinoma } \\
\text { lacrimal gland }\end{array}$ & 3 & 37,5 \\
\hline Sarcoma & 7 & 3,2 \\
\hline limfoma/limfoid ganas & 26 & 12 \\
\hline Metastasis & 3 & 1,4 \\
\hline Retinoblatoma (RB) & 51 & 23,5 \\
\hline Total & 760 & 100 \\
\hline
\end{tabular}

\section{PEMBAHASAN}

Kejadian kanker atau tumor mata di Indonesia jarang terlaporkan secara spesifik dan terbatas pada 
regional-regional daerah di Indonesia. Hasil penelitian tumor mata di RS Mata cicendo paling banyak diderita oleh laki-laki sebanyak laki-laki sebanyak 421 orang $(55,4 \%)$ dan 339 orang (44,6\%) merupakan perempuan.

Hal ini senada dengan laporan Mansur (2017), di RSUP. Dr. Wahidin Sudirohusodo, Makassar dari tahun 2014-2016 didapatkan 70 kasus tumor mata dengan jumlah perempuan (67,2\%) lebih banyak daripada laki-laki (32,8\%). Berdasarkan umur, jumlah balita (0-5 tahun) lebih banyak dengan kasus retinoblastoma (50\%). Jenis tumor mata yang didapatkan adalah tumor intraokular (58,6\%), tumor ekstraokular (40\%), dan retrobulbar $(1,4 \%){ }^{8}$

Hasil penelitian usia responden mayoritas $>$ dari 45 tahun sebesar sebanyak 330 orang $(43,4 \%)$. Hal tersebut bisa disebabkan oleh adanya riwayat paparan sinar matahari dalam waktu lang lama, dimulai dengan decade kedua kehidupannya, adanya riwayat genetik pada keluarganya maupun riwayat sistemik misalnya sindrom basal sel nevus yang sering disebut xeroderma pigmentosum ${ }^{9,10,11}$

Berdasarkan hasil penelitian menunjukkan mayoritas keterlibatan tumor orbita pada mata kiri sebanyak 389 orang $(51,18 \%)$ dimana lokasi tersering berdasarkan hasil penelitian di RS Mata Cicendo tahun 2017-2018 adalah di palpebra sebesar 140 orang (36\%). Tumor palpebra sangat umum, mudah dikenali secara klinis dan banyak dijumpai apalagi yang bersifat jinak, biasanya bertambah banyak seiring dengan bertambahnya usia. Tumor palpebra merupakan neoplasma atau benjolan abnormal pada daerah sekitar mata dan kelopak mata. Tumor palpebra dapat berasal dari unsur-unsur anatomis palpbra yaitu kulit, jaringan ikat, jaringan kelenjar, pembuluh darah, saraf, maupun dari otot sekitar palpebral. ${ }^{12}$ Tumor palpebra dibagi menjadi tumor jinak dan tumor ganas. Tumor ganas palpebral, kita dapat membaginya menjadi tumor primer dan tumor metastatik (jarang). ${ }^{13}$

Penatalaksanaan tumor orbita yang diberikan tidaklah sama, hal ini tergantung pada jenis tumor dan stadium saat tumor ditemukan. Penanganan tumor orbita memiliki tujuan guna memperoleh kesembuhan baik dari segi kosmetik yang baik maupun segi fungsional yang maksimal. Pada penelitian ini jenis operasi yang dijalani oleh responden mayoritas biopsi sebanyak 277 orang (36,4\%). Penatalaksanaan tumor orbita mempertimbangkan beberapa faktor seperti faktor tumor misalnya tipe tumor, ukuran lokasi, sifat penumbuhan dan apakah tumor primer atau rekurens. Faktor pasien, misalnya usia, riwayat penyakit lain, faktor psikologis dan riwayat pengobatan. ${ }^{14,15}$

Tumor orbita dapat didiagnosis melalui anamnesis, pemeriksaan oftalmologis, pemeriksaan status lokalis tumor, pemeriksaan penunjang misalnya CT Scan/MRI kepala baik dengan kontras maupun tidak dengan kontras kemudian dikonfirmasi dengan pemeriksaan histopatologi.

Penelitian ini mendapatkan hasil diagnosis klinis tumor jinak orbita tersering adalah kista sebanyak 116 orang $(22,4 \%)$. Hal ini sesuai dengan data penelitian Tailor et al (2013) yang menyatakan bahwa tumor orbita jinak tersering adalah kista dermoid. Tumor orbita memiliki angka kejadian yang sangat jarang,hanya sekitar 3,5\% - 4\% pada patologi mata. Urutan teratas tumor orbita pada anak yaitu kista dermoid, capillary hemangioma dan rhabdomyosarcoma, sedangkan pada dewasa yaitu tumor limfoid, cavernous hemangioma dan meningioma. ${ }^{3}$

Hasil penelitian diagnosis tumor ganas orbita tersering adalah limfoma maligna sebanyak 54 orang $(22,40 \%)$. Hal ini sesuai dengan penelitian Olsen dan Heegaard (2019), yaitu Limfoma orbita ditemukan sekitar 50-60\% merupakan limfoma okuler adneksa. Sebagian besar limfoma orbital berasal dari sel-B (97\%), di antaranya Ekstranodal Marginal Zone Limfoma (EMZL) (59\%) adalah subtipe yang paling umum, diikuti oleh Difuse Large B Cell Limfoma (DLBCL) (23\%), folikuler limfoma (FL) (9\%), dan limfoma sel mantel (MCL) (5\%). Limfoma orbitasering pada usia lanjut dengan gender bervariasi sesuai untuk subtipe limfoma. EMZL (53\%) dan FL (75\%) didominasi perempuan MCL didominasi laki-laki, sedangkan DLBCL distribusi gender yang merata. $80 \%$. Subtipe histopatologis dan keadaan klinis penyakit sebagai indicator outcame dan prognosis pasien. EMZL dan FL memiliki prognosis yang baik, sedangkan DLBCL dan MCL memiliki prognosis yang buruk. $^{16}$

Berdasarkan hasil penelitian ini menunjukkan histopatologi tumor jinak orbita tersering adalah 
radang sebanyak 92 orang (17\%) serta hasil histopatologi tumor ganas orbita tersering penelitian adalah epithelial ganas sebesar 94 orang (43\%), dimana squamous cell carcinoma menduduki peringkat pertama sebesar 47 orang (50\%). Hasil pemeriksaan histopatologis yang akurat menjadi sangat penting dalam kasus seperti ini, sehingga dapat menjadi rencana intervesi terapeutik dan penatalaksaan pembedahan di kasus tumor orbita. Pemeriksaan histopatologis diperlukan juga sebagai panduan menyingkirkan diagnosis banding yang ada. Sehingga keterangan klinis yang tepat mengenai diskripsi lokasi tumor, keterlibatan penyangga orbita, penyebarannya ke apex orbita atau sepanjang perineural dan intracranial dapat memberikan informasi apa yang terliat pada funduskopi sehingga akan memudahkan suatu tatalaksana tumor orbita. ${ }^{3,17}$ 18

Berdasarkan hasil uji Chi-square didapatkan $\mathrm{p}<$ 0,0001 dapat disimpulkan terdapat hubungan yang signifikan antara diagnosis klinis dengan hasil histopatologis, hal ini pula menunjukan bahwa semakin akurat diagnosis klinis maka semakin akurat dan tepat hasil histopatologis dan begitu juga dengan sebaliknya. Pemeriksaan histopatologi merupakan pemeriksaan goldstandar pada tumor orbita, meskipun pemeriksaan secara klinis juga hal yang penting. Keakuratan diagnosis klinis yang dikonfirmasi dengan hasil histopatologis pada tumor orbita sangat dibutuhkan untuk dapat digunakan dalam mengetahui perkembangan tumor yang lebih invasif dan merupakan acuan pemilihan terapi sesuai sehingga dapat menurunkan angka morbiditas maupun mortalitas pada tumor orbita. ${ }^{19}$

Diharapkan penelitian ini dapat dilanjutkan dengan meneliti variabel yang kurang dari penelitian ini misalnya riwayat pekerjaan pasien tumor orbita atau faktor risiko dari tumor mata itu sendiri sehingga semakin menambah wawasan kita tentang kejadian tumor mata.

\section{SIMPULAN}

Semakin akurat diagnosis klinis maka penentuan hasil histopatologis tumor orbita di RS Mata Cicendo Bandung semakin tepat dan akurat sehingga mencegah perkembangan tumor yang lebih invasif dan dapat sebagai acuan pemilihan terapi yang tepat serta dapat mengurangi angka morbiditas maupun mortalitas.

\section{UCAPAN TERIMA KASIH}

Alhamdulillah, puji syukur kehadirat Alloh SWT yang Maha Pengasih lagi Maha Penyayang atas rahmat dan karuniaNya sehingga peneliti dapat menyelesaikan penelitian ini dengan tepat waktu. Terima kasih kepada RS Mata Cicendo Bandung yang telah membantu memberikan dana pada penelitian ini.

\section{DAFTAR PUSTAKA}

1. Gondhowiardjo TD. Kompetensi dan perkembangan profesi. Ophthalmol Ina. 2017;43(2):105-7.

2. Oemiati R, Rahajeng E, Kristanto AY. Prevalensi tumor dan beberapa faktor yang mempengaruhinya di Indonesia. Buletin Penelitian Kesehatan. 2011; 39(2):190-204.

3. Tailor TD, Gupta D, Dalley RW, Dirk Keene C, Anza Y. Orbital neoplasms in adults: Clinical, radiologic, and pathologic review. Radiographics. 2013;33(6):1739-58

4. Bonham J, Ginat DT, Freitag SK. Imaging after orbital and intraocular oncology therapies. In PostTreatment Imaging of the Orbit. 2015;171-9.

5. American Academy of Ophthalmology. Basic and clinical science course, section 02 . In: Fundamentals and principles of ophthalmology. American Academy of Ophthalmology; 2017.

6. Setia M. Methodology series module 3: Crosssectional studies. Indian Journal of Dermatology. 2016;61(3): 261.

7. Dahlan MS. Besar sampel dalam penelitian kedokteran dan kesehatan. Epidemiologi Medika: 2016.

8. Mansur AP. Karakteristik penderita tumor mata di RSUP Dr. Wahidin Sudirohusodo periode 20142016 [skripsi]. Makassar: Fakultas Kedokteran. Universitas Hasanuddin. 2017.

9. American Academy of Ophtalmology. Orbital anatomy. In: Orbit, eyelids, and lacrimal system. chapter 1, section 7. American Academy of Ophtalmology. 2017 
10. American Academy of Opthalmology. Palpebral Tumours. Palpebral Tumours. [serial online]. 2012 (diunduh 29 November 2019). Tersedia dari: http://www.americanacademi.com/wpcontent/ ,uploads/2012/10/OS Chapter-12-Palpebraltumours.pdf

11. American Academy of Ophtalmology. Orbital anatomy. In: Orbit, eyelids, and lacrimal system. chapter 1, section 7. American Academy of Ophtalmology. 2017.

12. Khurana AK. Comprehensive Ophtalmology Ed.4rd. New Delhi: New age international ; 2007.

13. Eva PR, Whitcher JP. Vaughan \& Asbury Oftalmologi Umum. Edisi ke-17. Terj. Brahm UP. Jakarta: ECG; 2013.

14. Eldesouky MA, Elbakary MA. Clinical and imaging characteristics of orbital metastatic lesions among egyptian patients. Clinical Ophthalmology. 2015 Sep 10;9:1683-7.
15. Valenzuela AA, Archibald CW, Fleming B, Ong L, O'Donnell B, Crompton JJ, Sullivan TJ. Orbital metastasis: Clinical features, management and outcome. Orbit. 2009, 28(2-3):153-9.

16. Olsen TG, Heegaard S. Orbital lymphoma. Survey of Ophthalmology. 2019;64(1):45-66.

17. Khan SN, Sepahdari A.R. Orbital masses: CT and MRI of common vascular lesions, benign tumors, and malignancies. Saudi Journal of Ophthalmology. 2012;26(4):373-83.

18. Ushalatha B dan Sambasivarao. 2016 Role of CT in the evaluation of orbital tumors. IOSR-JDMS. 2016;15(4):16-9.

19. Gupta D, Dalley RW, Dirk Keene C, Anza Y. Orbital neoplasms in adults: Clinical, radiologic, and pathologic review. Radiographics. 2013 Oct;33(6):1739-58. 